\title{
足根骨癒合症に合併した足根管症候群の一例
}

\author{
長崎済生会病院 \\ 乗松崇裕・井上廣 \\ 宮 路 剛士 \\ 長崎友愛病院 \\ 寺本司
}

\section{Example of Tarsal Tunnel Syndrome Merged for Congenital Tarsal Coalition}

\author{
Takahiro Norimatsu, Hiroshi Inoue, and Tsuyoshi Miyaji \\ Department of Orthopaedic Surgery, \\ Saiseikai Hospital Nagasaki, Japan \\ Tsukasa Teramoto \\ Yuuai Hospital, Nagasaki, Japan
}

\begin{abstract}
We performed bloody therapy for a complicated tarsal tunnel syndrome case of comparatively rare congenital tarsal bone fusion symptoms, and obtained good results.

The patient was a 34-year-old firefighter complaining chiefly of numbness of the sole and pain. He underwent conservative treatment at another hospital, and the symptoms improved at one time.

However, symptoms aggravated again after skiing and operations were reguired. The operation ablated release of tarsal tunnel and adhesion department.

Spontaneous pain disappeared three days after operation and numbness one week after. He achieved full load gait, and there was rarely pain in gait.

Physical compression by ski boots is thought to aggravate symptoms.
\end{abstract}

Key words : tarsal tunnel syndrome（足根管症候群）, tarsal coalition（足根骨癒合症）

\section{は じめに}

足根骨癒合症に合併し生じたと思われる足根管症候 群は比較的希である。 今回我々は足根骨癒合症の中で 多く見られる距踵関節癒合症に対し観血的治療を行い 比較的良好な結果を得た 1 例を経験したので文献的考 察を加え報告する。

$$
\text { 症例 }
$$

34 歳, 男性, 消防士.

主訴：足底内側のしびれ感及び足関節内側の痛み
家族歴・既往歴：特記すべきこと無し

スポーツ：スキー

現病歴: 平成 13 年 11 月頃より足底内側前方のしび れ感を時折自覚していたが出現と寛解を繰り返すため に放置していた．平成 14 年 3 月スキー後より足関節 内側に痛みが出現した。しかし意識的に運動を抑制し， 活動レベルの低い部署に移ったこともあり, 徐々に痛 みが減少したためにそのまま様子を見ていた。しびれ 感は時折自覚していた.

同年 8 月後半頃より通常の消防訓練の後にも痛みが 出現するようになった．またしびれ感も消失しないよ 


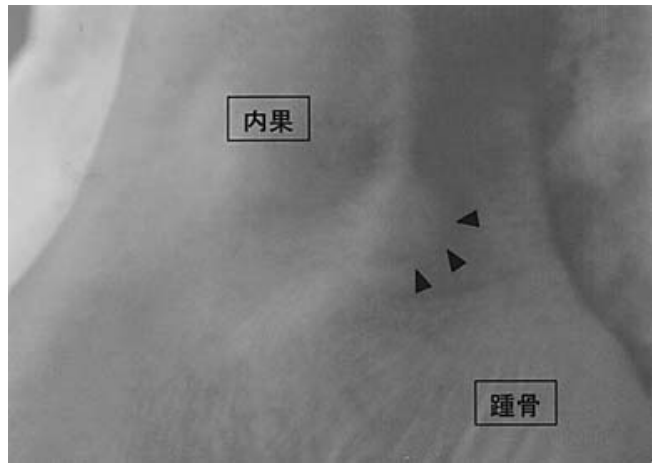

図 1 右足関節内側の肉眼的所見

内果後方に直径約 2 センチの骨性隆起を認める.

うになつたため 10 月近医受診した. しばらく固定や 物理学的療法といつた保存的加療を行うも症状改善し ないため 11 月当科受診となつた.

初診時身体所見：視診にて足関節内果後方に直径約 2 センチの骨性隆起を認めた（図 1)。同部に軽度の圧 痛及び tinnel’s sign を認めた。感覚障害については 右足底内側前方にしびれ感および触覚の低下を認めた. その領域は内側足底神経の支配領域とほぼ一致した （図 2). 足部には内外反制限を認めた。また足底筋の 萎縮や筋力の低下は認めなかった.

画像所見：単純レントゲン写真で左右ともに距踵関 節内側に癒合を認めた（図 3） CT では距骨踵骨双方 より隆起する病変をみとめた（図 4).

上記より距踵関節癒合症に合併した足根管症候群を 考え，癒合部の摘出手術を行つた.

手術所見：内側弓状切開にて進入した。足根管部で は一部静脈が拡張，蛇行した様な所見は，認めたもの の，距踵関節内側中部の骨性隆起の部位では神経の狭 窄，変性等は認めなかつた。また同部にガングリオン の存在も認めなかつた. しかし脛骨神経から分岐した 内側足底神経が骨性隆起部を越え，正常走行に戻る部 位にて強く屈曲を強いられ，同部にて神経の狭窄を認 めた（図 5)。ノミにて癒合部を切除し距踵関節を露 出した。麻酔下にて足部に約 10 度の内外反を認める ようになつた。術後写真を示す（図 6).

病理組織所見：切除した癒合部を距踵関節に直行す る様に切片を切り病理に提出した。癒合部は骨組織よ り軟骨組織に移行し, 双方の軟骨面は硝子様組織にて 癒合していた（図 7).
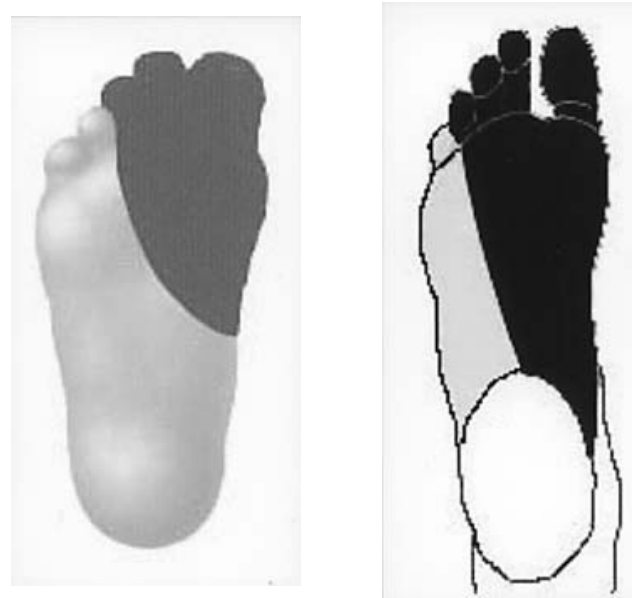

図 2 知覚障害出現領域 左 : 灰色にて示す部分が今回の障害部位. 右：黒にて示す部分が内側足底神経の支配領域.

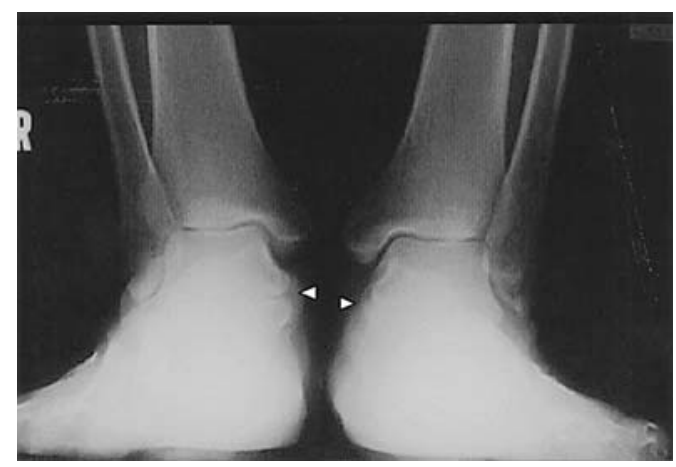

a

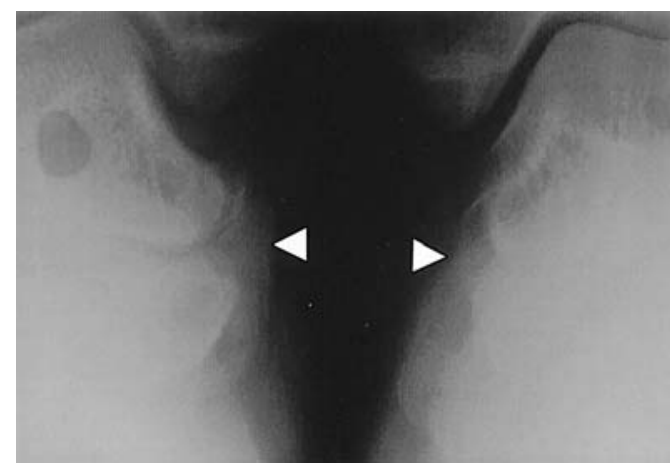

$\mathrm{b}$

図 3 単純 X 線像

a：左右距踵関節に隆起する癒合部を認める. $\mathrm{b}$ : 拡大図。 


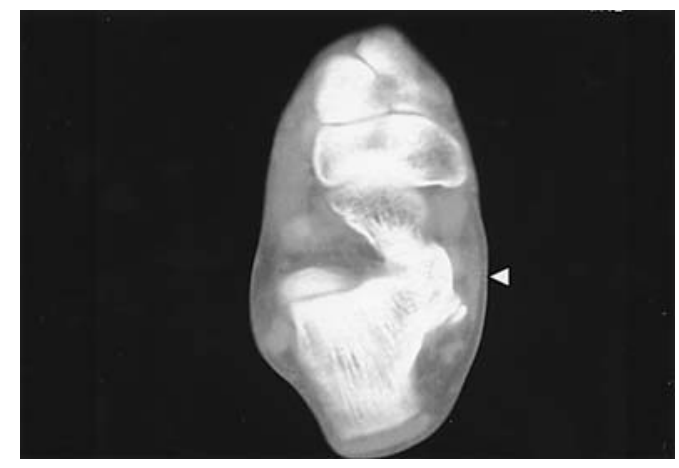

図 4 CT 像 距骨踵骨双方より隆起する癒合部を認める.

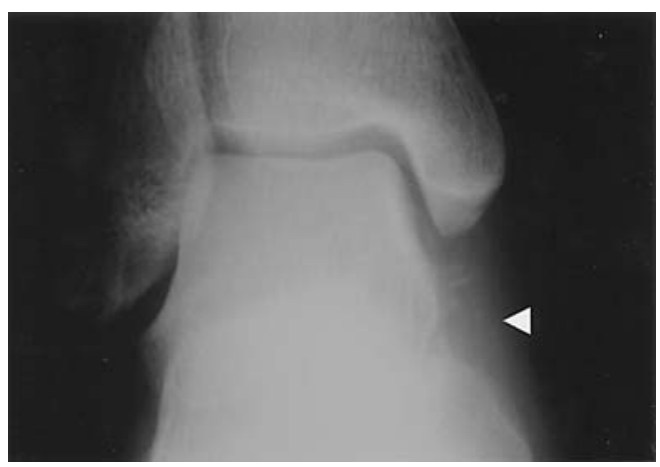

図 6 術後単純 X 線像

後療法 : 術後 1 週間シーネ固定を行い，その後はシー ネ除去し可動域訓練を開始した。術後 3 週目より部分 荷重開始し, 可及的速やかに荷重を増加した。術後 4 週目にはほぼ全荷重で歩行し, 痛みはなく跛行をごく 軽度認める程度であった。

結果 : 術翌日, 自発痛は消失, 感覚障害は 2 週間に てほぼ消失した。術後 3 力月現在通常生活を送ってい るが, 症状の再発は認めていない. 跛行も消失した.

\section{考察}

足根骨癒合症に伴う足根管症候群は比較的希とされ てきたが，最近はまとまった数の報告も散見される. 高岡ら ${ }^{5)}$ は 21 例 34 足を報告しそのうち 7 例 7 足がガ ングリオンを伴っていたとした。 そのうち 6 例に手術 を施行し良好な成績を収めている. 岡村, 竹村ら ${ }^{2) 6}$ はそれぞれ 1 例に観血的治療を行い良好な成績を得て いる.

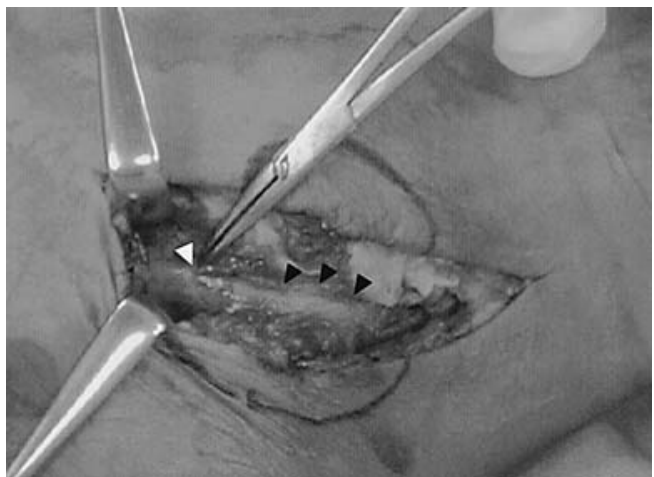

図 5 術中所見

白矢印：神経が骨隆起部を越え通常走行に戻る 部位にて神経の狭窄を示す。

黒矢印：骨性隆起を示す。その上を走行する神 経を認める.

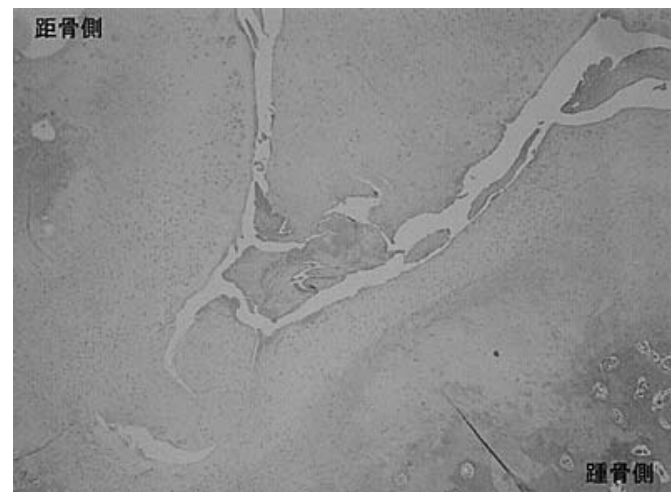

図 7 病理所見

癒合部は双方の骨組織から軟骨組織に移行し軟骨面の 間は硝子様組織にて癒合していた。

いずれも足根骨癒合症に関しては固定術ではなく癒 合部の切除による関節形成術を行っている，足根骨癒 合症に関する手術は関節形成術と関節固定術にわけら れるが Swiontkowski ら ${ }^{4)}$ は 40 症例の 15 年成績で形 成術の $20 \%$, 固定術の約半数に不満足な結果であつ たとしている．また症状を伴う足根骨癒合症は，その 手術に踏夕切るか否かが問題となってくるが， 小田 ら ${ }^{1)}$ は若年の先天性足根骨癒合症に保存的治療を行つ た 4 例を報告しその有効性と観血的治療にともなう周 囲関節への $\mathrm{OA}$ 変化の出現を指摘している. 今回の 症例は 34 歳と比較的年齢が高く, 職業柄, 編上げの ブーツを履き激しい活動を行う必要があり，仕事への 
早期復帰も望んでいた。 また趣味がスキーでこれから も続けたいという希望もあった. レントゲン上他の関 節の $\mathrm{OA}$ 変化は認めず, 症状も物理的占拠が原因で 癒合部以外の関節の関節症が原因となっている所見は 無かった. 以上の点を考え, 本人と話し合った結果, 局所への注射等は行わず手術を施行した．術式はその 後, 運動制限を来す可能性のある関節固定術は選ばず, 足根管の解放と癒合部の切除の夕行つた．今回の症例 は内側足底神経の支配領域に限局して症状が見られた。 これは内側足底神経が脛骨神経から分岐した後の走行 上に絞扼部位があったためと考えた。治療結果は上述 の通りで Olney の評価法 ${ }^{3)} の$ Excellent に相当した. 現在のところ距踵関節やその周囲関節に伴う痛みは出 現していないが，OA 変化を含め経時的に経過を観察 していく予定である. 今回の症例は骨性の隆起や足部 の可動のしにくさを 20 歳前後の頃より自覚しており, もともと先天的な瘾合があった部位に職業, 趣味での ブーツという物理的刺激が加わり, 発症したと推測し た.

\section{ま と め}

(1)内側足底神経麻痺を主体とする足根管症候群を呈 する距踵関節癒合症を経験した.

(2)関節形成術を施行し良好な結果を得た。

\section{参 考 文 献}

1）小田義直ら：当院における先天性足根骨癒合症 4 例の 治療成績. 整形外科と災害外科，37(1)：137-140, 1998.

2）岡村泰三ら：足根骨（距踵骨）癒合症の外科的治療経 験. 中部整災誌, $37(2) ： 415-416,1994$.

3) Olney, B. W. et al.: Excision of symptomatic coalition of the middle facet of the talocalcaneal joint. J. Bone Joint Surg., 69-A : 539-544, 1987.

4) Swiontkowski, M. F. et al.: Tarsal coalition: Longterm results of surgical treatment. J. Ped. Orthop., $3: 287-292,1983$.

5）高岡孝典ら：足根骨癒合症とガングリオンの合併によ る足根管症候群。中部整災誌, 41 : 697-698, 1998.

6）武村 剛ら：足根骨癒合症にガングリオンを伴った足 根管症候群の一例。関東整災誌，20 (1)：75-78，1989. 